\title{
REPOSISI KEWENANGAN ANTAR LEMBAGA NEGARA DALAM PENGATURAN TERKAIT PERTAHANAN KEAMANAN KEMARITIMAN NASIONAL
}

\author{
David Maharya Ardyantara, Kadi Sukarna, Bambang Sadono, Zaenal Arifin \\ Magister Hukum, Universitas Semarang, Semarang \\ davidardyantara@gmail.com
}

\begin{abstract}
Abstrak
Tujuan dari penelitian ini adalah untuk mengkaji bagaimana posisi kewenangan antar lembaga negara dalam pengaturan terkait pertahanan keamanan kemaritiman nasional dan bagaimana reposisi kewenangan antar lembaga negara dalam pengaturan terkait pertahanan keamanan kemaritiman nasional. Posisi dan reposisi tentang kewenangan antar lembaga negara yang terkait dengan pertahanan keamanan maritim nasional sangat berpengaruh kepada kedaulatan maritim nasional menuju Indonesia sebagai poros maritim dunia. Indonesia dapat digolongkan sebagai negara kepulauan tetapi belum dapat digolongkan sebagai negara maritim karena kewenangan dalam pertahanan keamanan maritim masih terjadi tumpang tindih kewenangan. Sehingga perlu dilakukan reposisi kewenangan antar lembaga negara dalam pengaturan terkait pertahanan keamanan kemaritiman nasional. Metodelogi penelitian yang digunakan adalah yuridis normatif. Berdasar analisa terdapat lima lembaga negara yang benar-benar terkait dengan pertahanan dan keamanan maritim di perairan Indonesia yang terdiri dari TNI AL,Badan Keamanan Laut,Kepolisian,Kesatuan Penjaga Laut dan Pantai, Direktorat Pengawasan Sumber Daya Kelautan Perikanan. Kedua peraturan perundangan ini secara spesifik menggarisbawahi pentingnya menciptakan sistem pertahanan keamanan maritim, dan kewajiban dalam menjaga keselamatan pelayaran. Pendekatan teoritik dilakukan mellaui Teori Sistem Hukum, Teori Kedaulatan dan Teori Kewenangan. Hasil yang didapatkan dalam reposisi kewenangan antar lembaga negara adalah : menempatkan TNI AL sebagai lembaga militer murni di wilayah maritim sebagai komponen utama pertahanan maritim nasional seperti diamanatkan pada Pengaturan Tata Ruang Laut yang tercantum dalam UU Nomor 17 tahun 1985 tentang ratifikasi UNCLOS 1982. Serta optimalisasi Bakamla sebagai koordinator tunggal lembaga sipil negara dalam keselamatan dan keamanan laut (sea and coast guard). Sekaligus sinegitas TNI dengan Bakamla sebagai reperesentasi lembaga militer dan lembaga sipil negara.
\end{abstract}

Kata kunci: Reposisi; Kewenangan; Pertahanan Keamanan Maritim 


\title{
REPOSITIONING OF AUTHORITY AMONG STATE INSTITUTIONS IN ARRANGEMENTS RELATED DUE TO NATIONAL MARITIME DEFENSE
}

\begin{abstract}
The purpose of this study is to examine the position of authority between state agencies in arrangements related to the defense of national maritime security and how to reposition authority between state agencies in arrangements related to the defense of national maritime security. The position and repositioning of the authority between the agencies of countries related to the defense of national maritime security has a profound effect on national maritime sovereignty towards Indonesia as the maritime axis of the world. Indonesia can be classified as an island nation but cannot yet be classified as a maritime country because the authority in maritime security defense still overlaps the authority. Ambiguity and confusion in the application of maritime defense and resilience, civil-military dichotomy and institutional sectoral ego spawned a policy of overlapping authority over the security of national maritime areas. So it is necessary to reposition the authority between state agencies in the arrangement related to the defense of national maritime security The methodology used is normative juridical. Based on analysis there are five state agencies that are really related to maritime defense and security in Indonesian waters consisting of the Navy, Marine Security Agency, Police, Marine and Coast Guard Unit, Directorate of Maritime Resource Supervision Fisheries. The establishment of Bakamla in Law No. 32/2014 on Marines gives rise to overlap of authority with Law No. 17/2008 on Shipping, because in the Marine Law does not mandate the formation of national marine and coastal guards. Both legislation specifically underscores the importance of creating maritime security defense systems, and the obligation to maintain shipping safety. Theoretical approaches are carried out through Legal System Theory, Sovereignty Theory and Theory of Authority. The result obtained in the repositioning of authority between state agencies is: placing the TNI AL as a pure military institution in the maritime region as the main component of national maritime defense as mandated in the Marine Spatial Arrangements set out in Law No. 17 of 1985 on the ratification of UNCLOS 1982. As well as optimizing Bakamla as the sole coordinator of the state civil agency in sea and coast guard security. At the same time, the TNI's synonym withBakamla as a reperesentasi of military institutions and civilian institutions of the state.
\end{abstract}

Keywords : Reposition; Authority; Maritime Defense 


\section{A. PENDAHULUAN}

Sejarah maritim Nusantara menunjukkan bahwa bangsa Indonesia pada masa lalu disegani bangsa lain di lautan dengan menjadi pusat perdagangan dan jalur pelayaran antar samudera, ${ }^{1}$ Alfred Thayer Mahan dalam karyanya yang monumental The Influence of Sea Power upon History: 1660-1783 menuliskan konsep kajian pertahanan dan keamanan terutama berfokus pada kekuatan maritim (sea power). Mahan menekankan pada pentingnya "controlling the great common of the sea" yang berpangkal pada pemberdayaan potensi kekuatan pertahanan keamanan maritim, yang apabila dioptimalkan akan meningkatkan taraf hidup dan menjaga kedaulatan suatu negara. ${ }^{2}$

Wilayah maritim Indonesia secara geostrategis terletak di persimpangan jalur utama SLOC dan SLOT antara Samudra Pasifik dan Samudra India serta Benua Asia dan Benua Australia, yang merupakan jalur utama antarnegara dalam ekonomi dan perdagangan. ${ }^{3}$ Ini berarti Indonesia berfungsi sebagai the global supply chain system dengan posisi geostrategis tersebut. ${ }^{4}$ Sehingga Indonesia menjadi pusat dalam jalur perdagangan dan pelayaran duinia yang membutuhkan lembaga negara yang khusus menangani keamanan dan keselamatan dalam pelayaran serta dikuatkan oleh perundang-undangan.

Posisi strategis tersebut berbatasan dengan 10 negara tetangga dan 11 provinsi yang berada di kawasan perbatasan laut. ${ }^{5}$ Posisi strategis Indonesia dengan geopolitiknya ${ }^{6}$ yang berada diantara dua benua dan dua samudera yang dilalui oleh ribuan kapal asing yang melintasi ALKI (Alur Laut Kepulauan Indonesia) dan selat-selat penting, disatu sisi menunjukkan strategisnya posisi geografis tersebut, namun disisi lain dapat menimbulkan kerawanan bagi kedaulatan maritim dari aspek pertahanan dan keamanan. Apabila tidak didukung oleg regulasi dan pelaksanaan yang jelas oleh lembaga-lembaga negara terkait.

Persepsi pertahanan keamanan maritim meliputi ruang lingkup yang kompleks dan saling terintegrasi. Terlepas adanya dua kepentingan laut yang saling mengikat, yaitu

\footnotetext{
${ }^{1}$ Harjo Susmoro, The Spearhead of Sea Power, Pandiva Buku, Yogyakarta 2019. Hal.19

2 Alfred Thayer Mahan, The Influence of Sea Power Upon History:1660-1783, Dover Publicatios Inc. New York 1987. Hal.73

${ }^{3}$ Yusuf Efendi, Wawasan Maritim Mengapa Belum Bergema?, Jalasena Edisi 3, 2013, hal 16,

${ }^{4}$ Darma Agung, Menata Keamanan Maritim Untuk Mnegakkan Kedaulatan Maritim Indonesia, Kompas Gramedia, Jakarta, hal 62

${ }^{5}$ Wahyono S.K., Indonesia Negara Maritim, Jakarta: Penerbit Teraju, 2009, hal. 4.

${ }^{6}$ Muhar Junef., Implementasi Poros Maritim Dalam Perspektif Kebijakan, Jurnal Penelitian Hukum De Jure 19 (3), 2019, hal 303-322. https://doi.org/10.30641/dejure.2019.V19.303-322
} 
e-ISSN : 2621-4105

kepentingan nasional dan kepentingan internasional. Pertama, laut bebas dari ancaman kekerasan yaitu ancaman menggunakan kekuatan bersenjata yang terorganisasi dan dinilai mempunyai kemampuan untuk menggangu dan membahayakan kedaulatan negara, baik berupa ancaman militer, pembajakan, perompakan, sabotase objek vital maupun aksi teror. Kedua, laut bebas dari navigasi yang ditimbulkan oleh kondisi geografi dan hidrogafi. Ketiga, laut bebas dari ancaman terdadap sumber daya laut berupa pencemaran dan perusakan ekosistem. Keempat, laut bebas dari ancaman pelanggaran hukum seperti illegal logging, illegal fishing, dan lainnya. ${ }^{7}$ Seiring dengan arah kebijakan pembangunan Indonesia saat ini, dimana kelautan menjadi faktor yang sangat penting dalam mendukung pembangunan khususnya dari sektor ekonomi, maka kini sudah saatnya bagi bangsa Indonesia untuk mengubah paradigmanya dari "Land Based SocioEconomic" menjadi "Marine Based Socio-Economic". 8

Penelitian ini terkait dengan penelitian Dhiana Puspitawati dan Kristiyanto (2017) yang berjudul "Urgensi Pengaturan Keamanan Maritim Nasional di Indonesia", penelitian tersebut menganalisa urgensi penetapan kerangka hukum nasional dalam keamanan maritime, dan metode yang digunakan adalah normatif dengan pendekatan perundangundangan serta studi komparasi. Hasil studi yang telah dilakukan yaitu: meskipun kerjasama internasional dan regional sangat penting dalam keamanan maritim, ketersediaan instrumen hukum nasional tentang keamanan maritim sangat diperlukan. ${ }^{9}$

Shanti Dwi Kartika (2014) dalam penelitiannya yang berjudul "Keamanan Maritim Dari Aspek Regulasi Dan Penegakan Hukum”, penelitian ini mengangkat permasalahan bagaimana pengaturan mengenai pengelolaan dan pengamanan wilayah maritim negara dalam peraturan perundang-undangan dan bagaimana penegakan hukum bidang kelautan di wilayah perairan laut Indonesia terkait dengan keamanan maritim negara? Hasil penelitian tersebut menyimpulkan bahwa kondisi perairan Indonesia sangat rentan akan berbagai ancaman kejahatan, terutama kejahatan transnational. Perairan Indonesia yang merupakan perairan yang paling berbahaya dimana paling sering terjadi berbagai ancaman maritim menyebabkan munculnya urgensi pengaturan keamanan maritim

\footnotetext{
${ }^{7}$ Bernard Kent Sondakh, Pengamanan Wilayah Laut Indonesia. Jurnal Hukum Internasional. Fakultas Hukum Indonesia. Jakarta, 2014 hal 39-48.

${ }^{8}$ Marsetio, Mengembalikan Kejayaan Maritim, Universitas Pertahanan, Jakarta 2018. hal. 30.

${ }^{9}$ Dhiana Puspitawati dan Kristiyanto, Urgensi Pengaturan Keamanan Maritim Nasional di Indonesia”, Jurnal Media Hukum 24(1), 2017, hal 12-23. http://dx.doi.org/10.18196/jmh.2017.0085.14-23
} 
e-ISSN : 2621-4105

nasional. Meskipun kerjasama internasional dan regional penting dalam menghadapi ancaman maritime, instrumen hukum nasional yang baik akan mendukung implementasi kerjasama internasional dan regional yang ada. Hukum nasional Indonesia masih belum sesuai dengan ketentuan internasional serta hukum nasional yang ada juga sudah out of date. Dengan demikian pengaturan secara nasional tentang keamanan maritim sangat diperlukan, guna mengatasi ancaman maritim, kerangka hukum nasional yang komprehensif sangat diperlukan. ${ }^{10}$

Sedangkan penelitian Syaiful Anwar (2016) tentang membangun keamanan maritim Indonesia dalam analisa kepentingan, ancaman dan kekuatan laut mengkaji ancaman terhadap kepentingan nasional di bidang maritim, serta upaya-upaya yang diperlukan dalam membangun kekuatan maritim Indonesia. Hasil penelitian ini adalah adanya ancaman di wilayah perairan Indonesia antara lain pembajakan di laut, penangkapan ikan secara ilegal, sengketa wilayah antar negara, penyelundupan narkotika, serta penyelundupan manusia. Adapun unsur-unsur yang menjadi lingkup dari keamanan maritim Indonesia adalah kedaulatan negara dan keutuhan wilayah, laut yang bebas dari pelanggaran hukum, keamanan dan keselamatan pelayaran, serta keamanan dan kelestarian sumber daya maritim. Terdapat tujuh faktor penting yang perlu diperhatikan atau dibenahi, yaitu kebijakan pemerintah, kekuatan angkatan laut, kekuatan unsur-unsur keamanan laut, kekuatan armada kapal dagang, sumber daya manusia, perdagangan di dan lewat laut, serta pelabuhan laut. ${ }^{11}$

Fungsi pelaksanaan pertahanan dan keamanan maritim harus difokuskan secara sinergis dan integratif antar instansi atau lembaga terkait. Pertimbangan yang diambil adalah seharusnya terdapat mekanisme sinergis yang terintegrasi antara pengawasan lalu lintas laut, manusia dan barang di sejumlah pintu masuk pelabuhan laut. Namun, ego sektoral seringkali menjadi kendala untuk pengembangan sinergitas seperti sudah disebutkan di atas. Sehingga instansi yang berwenang melakukan fungsi koordinatif malah berjalan menurut persepsi masing-masing. ${ }^{12}$

\footnotetext{
${ }^{10}$ Shanti Dwi Kartika, “Keamanan Maritim Dari Aspek Regulasi Dan Penegakan Hukum”, Jurnal Negara Hukum 5(2), 2014, hal 142-167. http://dx.doi.org/10.22212/jnh.v5i2.238

${ }^{11}$ Syaiful Anwar, Keamanan Maritim Indonesia Dalam Analisa Kepentingan, Ancaman Dan Kekuatan Laut, Jurnal Pertahanan 6(3), 2016, hal 69-89.

${ }^{12}$ Victor Muhamad Simela, Indonesia Menuju Poros Maritim Dunia, Jurnal Info Singkat Hubungan Internasional 6(21), 2014 hal $78-89$.
} 
Pemerintahan Indonesia di bawah kepemimpinan Presiden Joko Widodo melalui Peraturan Presiden Nomor 178 Tahun 2014, mendirikan Badan Keamanan Laut (Bakamla) yang sebelumnya bernama Badan Koordinasi Keamanan Laut (Bakorkamla). Bakorkamla, yang awalnya hanya menjalankan fungsi sebagai pengawas ditataulang pada tanggal 8 Desember 2014 menjadi Badan Keamanan Laut Indonesia (Bakamla) dengan wewenang yang lebih luas sampai dengan kewenangan untuk menindak segala bentuk kejahatan di laut. Hal ini menimbulkan pro dan kontra, karena persoalan utama yang terjadi adalah kurangnya koordinasi antar lembaga, bukan membuat lembaga baru. ${ }^{13}$

Gubernur Lemhannas RI Agus Widjojo dalam bukunya yang berjudul, Transformasi TNI dari Pejuang Kemerdekaan menuju Tentara Profesional dalam Demokrasi: Pergulatan TNI Mengukuhkan Kepribadian dan Jati Diri, dalam salah satu fokus perhatiannya adalah pembagian wewenang perihal pertahanan dan keamanan maritim. Dalam prakteknya pertahanan dan keamanan maritim adalah murni tanggung jawab TNI Angkatan Laut. Menurut Agus Widjojo ${ }^{14}$ perlu penempatan kembali pertahanan dan keamanan maritim yang merupakan fungsi penegakan hukum di wilayah maritim nasional yang harus dilaksanakan secara sinergi antara TNI bersama dengan lembaga sipil terkait.

Kebaharuan penelitian dalam artikel ini adalah penempatan reposisi kewenangan lembaga terkait pertahanan dan keamanan maritim nasional berdasarkan (1) Pengaturan Tata Ruang Laut yang tercantum dalam UU Nomor 17 tahun 1985 tentang ratifikasi UNCLOS 1982, dimana reposisi kewenangan dibedakan berdasar tata ruang laut mulai dari Perairan Pedalaman, Perairan Kepulauan,Laut Teritorial, Zona Tambahan, Zona Ekonomi Eksklusif dan Landas Kontinen; (2) Berdasarkan Lembaga Militer dan Lembaga sipil, dimana lembaga militer menjadi kewenangan TNI AL dan lembaga sipil dibawah Bakamla selaku Single Agency Multi Task / SAMT / Koordinator Tunggal.; (3) Pembentuksn perundangan baru untuk menegaskan wewenang, fungsi dan peran Bakamla selaku Koordinator Tunggal dalam lembaga sipil dalam kaitan pertahanan keamanan maritim nasional. Sekaligus sebagai harmonisasi UU no 32 tahun 2014 tentang

\footnotetext{
${ }^{13}$ Rujito Dibyo Asmoro, Peran Indonesia dalam Menjaga Stabilitas guna Mewujudkan Indonesia sebagai Negara Poros Maritim Dunia. Jurnal Kajian Lemhannas RI.Jakarta Edisi 36, 2018. Hal 87-103

${ }^{14}$ Agus Widjojo, Transformasi TNI dari Pejuang Kemerdekaan menuju Tentara Profesional dalam Demokrasi: Pergulatan TNI Mengukuhkan Kepribadian dan Jati Diri. Penerbit Obor. Jakarta. 2014. Hal 78.
} 
e-ISSN : 2621-4105

Kelautan dan UU No. 17 tahun 2008 tentang Pelayaran. Tujuan dari penelitian ini adalah untuk mengkaji bagaimana posisi kewenangan antar lembaga negara dalam pengaturan terkait pertahanan keamanan kemaritiman nasional dan bagaimana reposisi kewenangan antar lembaga negara dalam pengaturan terkait pertahanan keamanan kemaritiman nasional.

\section{B. PERMASALAHAN}

Berdasarkan latar belakang tersebut, maka perumusan masalah dalam artikel ini adalah (1) Bagaimana posisi kewenangan antar lembaga negara dalam pengaturan terkait pertahanan keamanan kemaritiman nasional? (2) Bagaimana reposisi kewenangan antar lembaga negara dalam pengaturan terkait pertahanan keamanan kemaritiman nasional?

\section{LANDASAN TEORITIS}

Metode penulisan mempergunakan metode yuridis normatif dengan mempergunakan perundang-undangan terkait seperti UU Kelautan, UU Pelayaran, UU TNI, UU Perikanan dan UU Kepolisian yang dikaitkan dengan UNCLOS 1982 dan ratifikasinya. Spesifikasi penelitian yang dipergunakan adalah penelitian analisis deskriptif yaitu metode pencarian fakta dengan interpretasi yang tepat. Sehingga tergambar mengenai situasi atau kejadian secara lebih umum dari materi-materi yang relevan dan mengana;lisis data mengacu pada pengetahuan yuridis

Teori yang dipakai dalam penulisan artikel ini adalah (1) Teori Sistem Hukum dari Lawrence M Friedman mengemukakan bahwa efektif dan berhasil tidaknya penegakan hukum tergantung tiga unsur sistem hukum, yakni struktur hukum (structure of the law) substansi hukum (substance of the law)dan budaya hukum (legal culture). ${ }^{15}$ Struktur hukum menyangkut aparat penegak hukum, substansi hukum meliputi perangkat perundang-undangan dan budaya hukum merupakan hukum yang hidup (living law) yang dianut dalam suatu masyarakat; (2) Teori kedaulatan.dari Jean Bodin sebagai salah satu tokoh dalam teori kedaulatan mengemukakan bahwa kedaulatan merupakan the absolute and perpetual power of commonwealth. Commonwealth ini berarti merupakan pemerintahan yang benar, terdiri dari anggota-anggota yang bersifat kekeluargaan dan memiliki kepentingan bersama yang sama, dan didasarkan oleh kekuatan yang berdaulat. 16 (3) Teori Kewenanangan dari Phillipus M. Hadjon dimana Kewenangan sering

\footnotetext{
${ }^{15}$ Lawrence M. Friedman, American Law. New York: W.W. Norton \& Company,1984, hal. 24.

16 Jean Bodin, On Sovereignty: Four Chapters from the Six Books of the Commonwealth, Edited by Julian H. Franklin, (Cambridge: Cambridge University Press, 1992), hal. 17.
} 
e-ISSN : 2621-4105

disejajarkan dengan istilah wewenang. Istilah wewenang digunakan dalam bentuk kata benda dan sering disejajarkan dengan istilah "bevoegheid" dalam istilah hukum Belanda. Menurut Phillipus M. Hadjon, jika dicermati ada sedikit perbedaan antara istilah kewenangan dengan istilah "bevoegheid". Perbedaan tersebut terletak pada karakter hukumnya. Istilah "bevoegheid" digunakan dalam konsep hukum publik maupun dalam hukum privat. ${ }^{17}$

\section{PEMBAHASAN}

\section{Posisi Kewenangan Antar Lembaga Negara Dalam Pengaturan Terkait}

\section{Pertahanan Kemaritiman Nasional}

Indonesia belum menjadi negara maritim sepenuhnya karena belum dapat memanfaatkan dan mengelola potensi kemaritiman secara optimal. Meskipun bidang kemaritiman sangat menjanjikan bagi kemakmuran bangsa. Kendala yang paling utama adalah maritim belum menjadi arus utama dalam pembangunan nasional, pemerintah lebih mengarusutamakn pembangunan daratan (land-based oriented). Hal ini menurut penulis menjadi dasar untuk penyusunan reposisi kewenangan dalam pertahanan dan keamanan maritim nasional.

Pertahanan dan Keamanan maritim Indonesia sampai saat ini masih bersifat sektoral karena lembaga-lembaga yang terkait didalmnya masih bersifat sektoral. Kewenangan pertahanan dan keamanan maritim yang dilaksanakan oleh lembaga pemerintah mengakibatkan keberagaman pendapat dalam penerapannya. Interpretasi ini mendorong penguasa atau pemerintah untuk menerjemahkan sesuai dengan kepentingannya. ${ }^{18}$

Berdasar analisa terdapat lima lembaga negara yang benar-benar langsung berkaitan dengan pertahanan dan keamanan maritim di perairan Indonesia yang terdiri dari (1)TNI AL (Undang-undang Nomor 4 tahun 2004 tentang TNI); (2) Badan Keamanan Laut (Undang-undang Nomor 32 tahun 2014 tentang Kelautan); (3) Kepolisian (Undang-undang Nomor 2 tahun 2004 tentang Kepolisian RI); (4) KPLP (Undang-Undang Nomor 17 tahun 2008 tentang Pelayaran); (5) Pengawasan Sumber Daya Kelautan Perikanan (Undang-Undang Nomor 31 Tahun 2004 tentang Perikanan

\footnotetext{
${ }^{17}$ Philipus Hadjon, Tentang Wewenang, Yuridika, Nomor 5\&6 XII September-Desember 1999.

${ }^{18}$ Christian Bueger.2015."What is Maritime Security?". Marine Policy 53, 2015, hal 159-164.
} 
e-ISSN : 2621-4105

Hasil analisa menunjukkan reposisi kewenangan berdasarkan amanat UU No. 5 Tahun 1983 tentang ZEEI dan UU No. 6 tahun 1996 tentang Perairan Indonesia, UU No. 32 Tahun 2014 tentang Kelautan dan UU No 17 tahun 2008 menunjukkan bahwa di Zona Ekonomi Eksklusif Indonesia adalah TNI AL dan Bakamla. Termasuk didalamnya wilayah pengusahaan perikanan Indonesia yang terdiri atas laut teritorial Indonesia, perairan kepulauan, dan perairan pedalaman Indonesia, serta ZEEI.

Pembentukan kesatuan penjaga laut dan pantai dalam fungsi tersebut (dalam UNCLOS 1982 disebut "coast guards ") yang diamanatkan dalam UU Pelayaran adalah Kesatuan Penjagaan Laut dan Pantai Indonesia (KPLP) yang berada di bawah Kementerian Perhubungan. UU Pelayaran merangkum seluruh peraturan dalam aktifitas pelayaran di perairan Indonesia. Terutama dalam hal keamanan dan keselamatan pelayaran, perundangan lain diharuskan tunduk (bagian Penjelasan UU Pelayaran). UU Pelayaran pasal 276 mengamanatkan pembentukan penjaga laut dan pantai. yang bertanggung jawab kepada Presiden, dan secara teknis dilaksanakan oleh Menteri. Selanjutnya dalam Pasal 278 menyebutkan bahwa penjaga laut dan pantai mempunyai kewenangan melaksanakan patroli laut, pengejaran seketika (hot pursuit), memberhentikan dan melakukan pemeriksaan kapal di wilayah laut.

Penjagaan laut dan pantai memegang peranan penting dalam pertahanan dan keamanan maritim nasional hal tersebut tampak pada amanat UU Pelayaran untuk dukungan pangkalan di seluruh wilayah, penggunaan status kapal/pesawat negara (Pasal 279), sampai dengan kewenangan khusus penyidikan bidang pelayaran oleh penyidik pegawai negeri sipil (PPNS) dalam segala otoritasnya (Pasal 282-283).

Pembentukan Bakamla dalam Pasal 59 UU Nomor 32/2014 memunculkan tumpang tindih dengan UU Pelayaran, karena dalam UU Kelautan tidak mengamanatkan pembentukan penjaga laut dan pantai nasional. Kewenangan Bakamla dalam hal pendirian pangkalan, penggunaan kapal/pesawat berstatus negara, dan sebagai unsur Kementrian/ (KKP) dalam hal kelautan sama sekali tidak diamanatkan dalam UU Kelautan.

Pemerintah Indonesia dalam beberapa kali kejadian penerobosan wilayah Laut Natuna Utara mengalami dampak dari tumpang tindih kedua peraturan perundangan tersebut. KPLP memiliki otoritas, format kelembagaan dan prosedur operasi yang diamanatkan dalam UU namun di lapangan sangat lemah dalam menghadapi penerobosan 
e-ISSN : 2621-4105

wilayah pmaritim nasional. Bakamla pun hanya mendapatkan otoritas untuk sekadar melakuakn tindakan mendekati kapal asing dengan harapan akan keluar dari wilayah Indonesia. UU Kelautan mengenai Bakamla pada Pasal 65 bertolak belakang dengan UU TNI, UU Kelauatan Pasal 65 menyebutkan bahwa kepala Bakamla dijabat oleh personal dari instansi penegak hukum yang memiliki kekuatan armada patroli. UU TNI dalam Pasal 47 menjelaskan tentang batasan bahwa prajurit aktif hanya boleh menjabat di 10 instansi (Kemenko Polhukam, Kemenhan, Setmilpres, BIN, BSN, Lemhanas, DPN, SAR, BNN, dan MA). Kenyataan di lapangan pejabat tinggi Bakamla formasinya diisi oleh para perwira tinggi aktif TNI AL.

UU Kelautan Pasal 62-63 menerangkan bahwa kewenangan laut berada dalam satu komando dan kendali Bakamla. Namun dalam pertahanan dan keamanan maritim terdapat 24 aturan perundangan yang tidak bisa dilaksanakan dibawah satu jalur komando karena kedudukannya setingkat. Apabila Bakamla dipaksakan oleh pemerintah menjadi single task multi agency, maka selayaknya diamanatkan dalam suatu perundangundangan tersendiri.

Indonesia sampai dengan saat ini masih belum fokus dalam menindaklanjuti urgensi tata kelola pertahanan kemaanan maritim. Persoalan ini menurut penulis dapat ditelusuri melalui implementasi dari teori Friedman yakni sustansi hukum, struktur kelembagaan, dan kultur. Kerangka hukum berfungsi untuk menyediakan seperangkat regulasi tentang pertahanan keamanan maritim. Kemudian sumberdaya yang meliputi kapabilitas dan sistem pembagian wilayah, personel dan pelatihan yang terintegrasi.. Sedangkan aspek kelembagaan meliputi sinergitas dan koordinasi antar lembaga negara terkait pertahanan keamanan maritim serta pelibatan sistem informasi. Mengandalkan undang-undang untuk membangun budaya maritim nasional yang berkarakter tunduk, patuh dan terikat pada norma hukum sangat sesuai dalam tata kelola pertahanan keamanan maritim nasional..

Kerangka substansi hukum sangat berperan besar dalam menerjemahkan legitimasi lembaga-lembaga terkait pertahanan keamanan maritim nasional. Indonesia dewasa ini hanya memiliki dua peraturan perundangan yang benar-benar berkaitan dengan maritim ysitu UU Nomor 32 Tahun 2014 tentang Kelautan dan UU Nomor 17 Tahun 2008 tentang Pelayaran. Kedua peraturan perundangan ini secara spesifik menggarisbawahi pentingnya menciptakan sistem pertahanan maritim, dan kewajiban aktivitas dalam keselamatan 
e-ISSN : 2621-4105

pelayaran. Namun keduanya tidak secara spesifik menyatakan suatu sistem perlindungan wilayah maritim nasional yang mengintegrasikan lembaga-lembaga terkait dengan pembagian fungsi dan peran yang jelas. Tulisan ini menyatakan sangat pentingnya membuat grand design atau cetak biru sebagai dasar hukum untuk memperjelas langkahlangkah konkrit dalam pengelolaan pertahanan keamnanan maritim di Indonesia. Sehingga dapat menjadikan sinergisitas antar lembaga bukan menimbulkan tumpang tindih kewenangan dalam pelaksanaan pertahahan keamanan maritim.

Wilayah maritim yang diakui secara yuridis sebagai wilayah kedaulatan negara Indonesia mempunyai konsekuensi bahwa negara Indonesia berdaulat sepenuhnya untuk mendiami dan mengelola wilayah tersebut. Sesuai dengan pernyataan Jean Bodin dalam teori kedaulatan bahwa kedaulatan negara muncul bersamaan dengan berdirinya suatu negara. Kedaulatan Negara merupakan kedaulatan yang berasal dari negara itu sendiri. Kedaulatan adalah kekuasaan tertinggi dalam suatu negara yang berlaku terhadap seluruh wilayah dan segenap rakyat dalam negara tersebut. ${ }^{19}$ Kedaulatan negara menjadi hak dasar dan hak tertinggi, baik secara alamiah, de jure maupun de facto. Kedaulatan bagi Indonesia menjadi tujuan dan kerangka untuk mencapai cita-cita nasional dalam Pereambule Undang-Undang Dasar 1945.

Fokus utama tulisan ini bahwa pemerintah dalam melakukan pembangunan postur lembaga terkait pertahanan dan keamanan maritim nasional untuk mengantisipasi ancaman dan tantangan terhadap pertahanan dan keamanan maritim.. Namun pemerintah belum dapat mewujudkannya karena terjadi ambiguitas dan kerancuan dalam penerapan pertahanan dan ketahanan maritim, dikotomi sipil-militer serta ego sektoral kelembagaan, terhadap TNI AL, Bakamla, Polri, KPLP, Bea Cukai, Imigrasi dan PSDKP. melahirkan kebijakan yang tumpang tindih terhadap pengamanan wilayah maritim nasional.

\section{Reposisi Kewenangan Dalam Pertahanan Keamanan Maritim}

Dalam artikel ini kondisi geografis inilah menjadi titik awal pemikiran dalam merumuskan reposisi lembaga-lembaga negara yang terkait dalam pertahanan dan keamanan maritim nasional. Bersamaan dengan hal tersebut diharapkan lembagalembaga tersebut dapat memiliki pemahaman yang bulat dan utuh tentang bagaimana

${ }^{19}$ A. Octavian, Sosiologi Maritim : Rezim Pengelolaan Maritim Indonesia, .Jurnal Kajian Lemhanas RI Ed. 14, 2012, hal 63-84. 
e-ISSN : 2621-4105

posisi mereka sebenarnya dalam penyelenggaraan pertahanan dan keamanan maritim Indonesia.

Reposisi kewenangan pertahanan keamanan maritim ditandai dengan kondisi wilayah maritim nasional yang terbebas dari segala ancaman, maka selain kondisi geografis, upaya identifikasi ancaman keamanan maritim di Indonesia menjadi salah satu unsur utama. Sesuai yang dinyatakan oleh Cribb (2009) menyatakan bahwa secara garis besar ancaman-ancaman pertahanan dan keamanan maritim di Indonesia dapat dikategorikan menjadi 2 (dua), yaitu ${ }^{20}$ (i) kejahatan yang memanfaatkan laut sebagai obyek (seperti IUU fishing, illegal waste dumping, dan illegal poaching), dan (ii) kejahatan yang memanfaatkan laut sebagai sarana(seperti penyelundupan manusia dan perdagangan orang serta pembajakan dan perampokan bersenjata di laut).

Indonesia sampai saat ini belum layak disebut sebagai negara karena belum dapat memanfaatkan dan mengelola potensi kemaritiman secara optimal. Menurut Penulis, pemerintah dalam RPJPN maritim belum menjadi arus utama dalam pembangunan nasional, pemerintah lebih mengarusutamakan pembangunan daratan (land-based oriented). Hal ini menurut penulis menjadi dasar untuk penyusunan reposisi kewenangan dalam pertahanan dan keamanan maritim nasional. Hal ini sesuai dengan gambaran masalah pertahanan maritim di Indonesia, sebagaimana diungkapkan Laksdya TNI Dr. Desi Albert Mamahit, M.Sc., ada empat hal yaitu kecenderungan keamanan laut, disparitas pembangunan kelautan, regulasi dan kelembagaan, serta infrastruktur pertahanan dan keamanan. ${ }^{21}$ Terkait dengan masalah kecenderung keamanan laut, hingga saat ini masih marak terjadi aktivitas pencurian ikan (illegal fishing) dan sumber daya alam lainnya yang dapat mengancam kehidupan sosial ekonomi masyarakat. Selain masalah pencurian sumber daya alam, juga diperparah dengan masih terdapatnya sejumlah kekerasan di laut berupa pembajakan, perompakan, dan sabotase.

Artikel ini memetakan reposisi kewenangan lembaga terkait hankam maritim berdasarkan (1) pembagian tugas sipil dan militer. TNI AL mendapatkan porsi penuh untuk pertahanan dan keamnan maritim sesuai UU Pertahanan Negara dan UNCLOS 82.

\footnotetext{
${ }^{20} \mathrm{R}$. Cribb, Indonesia as an Archipekago : Managing Islands, Managing the Seas. Institute of Southeast Asian Studioes, Singapore.2009, hal. 127.

${ }^{21}$ Kandar, Memanfaatkan Konflik di Laut Tiongkok Selatan Guna Meningkatkan Stabilitas Keamanan Nasional, Jurnal Kajian Lemhannas RI, Edisi 36. Desember 2018. hal 54-68.
} 
e-ISSN : 2621-4105

Sedangkan Bakamla menjadi sinle agency yang mengkoordinasikan lembaga-lembaga sipil baik KKP, Kemenhub, Bea Cukai dan POLRI. Reposisi kewenangan ini memberikan atribusi berupa kewenangan kelembagaan untuk menegakan pertahanan keamann maritim nasional sesuai dengan materi muatan yang diatur dalam undang-undang. Sesuai dengan teori kewenangan yang disampaikan oleh Philipus M Hadjon bahwa atribusi dapat dinyatakan juga sebagai suatu mekanisme untuk mendapatkan wewenang dalam pemerintahan. Dengan demikian jelas bahwa kewenangan yang diperoleh melalui atribusi yang dilakukan oleh lembaga pemerintah merupakan kewenangan asli, disebabkan kewenangan tersebut didapatkan langsung dari konstitusi atau perundangan. Melakukan pengkategorian perundang-undangan mengenai kemaritiman menjadi dua, yaitu pertama, undang-undang yang bersifat umum, seperti UU Pertahanan; dan kedua, undang-undang yang seluruhnya mengatur laut, seperti UU Kelautan, UU Perairan, UU ZEE; UU Perikanan, UU Pelayaran. Sehingga pengkategorian tersebut menjadi dasar reposisi kewenangan dari lembaga-lembaga terkait pertahanan keamanan maritim.

Tulisan ini menempatkan reposisi kewenangan lembaga terkait pertahanan dan keamanan maritim nasional berdasarkan :1) Pengaturan Tata Ruang Laut yang tercantum dalam UU Nomor 17 tahun 1985 tentang ratifikasi UNCLOS 1982, dimana reposisi kewenangan dibedakan berdasar tata ruang laut mulai dari Perairan Pedalaman, Perairan Kepulauan,Laut Teritorial, Zona Tambahan, Zona Ekonomi Eksklusif dan Landas Kontinen (2)Berdasarkan Lembaga Militer dan Lembaga sipil, dimana lembaga militer menjadi kewenangan TNI AL dan lembaga sipil dibawah Bakamla selaku Singel Agency Multi Task /SAMT/Koordinator Tunggal. (3) Pembentukan perundangan baru untuk menegaskan wewenang, fungsi dan peran Bakamla selaku Koordinator Tunggal dalam lembaga sipil dalam kaitan pertahanan keamanan maritim nasional. Sekaligus sebagai harmonisasi UU No 32 tahun 2014 tentang Kelautan dan UU No. 17 tahun 2008 tentang Pelayaran.

\section{E. PENUTUP}

Posisi kewenangan antar lembaga negara terkait pertahanan keamanan emaritiman yang tumpang tindih saat ini menyebabkan Indonesia mengalami ancaman dan gangguan yang berimplikasi pada pertahanan keamanan maritim negara. Ada lima lembaga yang benar-benar terkait langsung dengan pertahanan keamanan maritim yang masing-masing mempunyai kewenangan yang diberlakukan di kawasan maritim nasional, namun sampai 
e-ISSN : 2621-4105

saat ini kewenangan tersebut masih bersifat sektoral sehingga timbul disharmonisasi dan tumpang tindih peraturan dan kewenangan dalam pertahanan keamanan laut. Sehingga pemerintah belum dapat memposisikan kewenangan antar lembaga terkait hankam maritim tersebut karena terjadi ambiguitas dan kerancuan yang berupa dikotomi sipilmiliter, kerancuan wilayah kewenangan dalam hankam maritim, dan ego sektoral kelembagaan, yang menimbulkan tumpang tindih kewenangan terhadap kedaulatan wilayah maritim nasional. Reposisi kewenangan antar lembaga negara yang dilakukan adalah : menempatkan TNI AL dalam kewenangannya sebagai lembaga militer murni di wilayah maritim sebagai komponen utama pertahanan maritim nasional seprrti diamanatkan pada Pengaturan Tata Ruang Laut yang tercantum dalam UU Nomor 17 tahun 1985 tentang ratifikasi UNCLOS 1982, dimana reposisi kewenangan dibedakan berdasar tata ruang laut mulai dari Perairan Pedalaman, Perairan Kepulauan,Laut Teritorial, Zona Tambahan, Zona Ekonomi Eksklusif dan Landas Kontinen. Reposisi kewenangan terhadap Bakamla sebagai harmonisasi UU 17 tahun 2008 tentang Pelayaran dan UU 32 tahun 2014 tentang Kelautan perlu dipertegas dengan peraturan perundangan tersendiri. Sehingga optimalisasi Bakamla sebagai satu-satunya lembaga koordinator dalam keselamatan dan keamanan laut (sea and coast guard) dapat dilaksanakan. Baik fungsinya selaku koordinasi antar lembaga sipil maupun dengan TNI. Sehingga dengan demikian wilayah kewenangan Bakamla mulai dari laut pedalaman sampai dengan ZEEI. Apabila reposisi kewenangan antar lembaga terkait hankam maritim tersebut dapat tercapai maka akan terwujud tujuan dan cita-cita nasional bangsa Indonesia sebagaimana tersirat dalam Pembukaan UUD 1945.

\section{DAFTAR PUSTAKA}

\section{Buku}

Agus Widjojo, Transformasi TNI dari Pejuang Kemerdekaan Menuju Tentara Profesional Dalam Demokrasi: Pergulatan TNI Mengukuhkan Kepribadian dan Jati Diri. Penerbit Kartika. Jakarta. 2014.

Alfred Thayer Mahan, The Influence of Sea Power Upon History, Dover Publicatios Inc. New York 1987.

Darma Agung, Menata Keamanan Maritim Untuk Mnegakkan Kedaulatan Maritim Indonesia, Kompas Gramedia, Jakarta.

Bodin,Jean. On Sovereignty: Four Chapters from the Six Books of the Commonwealth, Edited by Julian H. Franklin, (Cambridge: Cambridge University Press, 1992.

Harjo Susmoro, The Spearhead of Sea Power, Pandiva Buku, Yogyakarta 2019 Lawrence M. Friedman.. American Law. New York: W.W. Norton \& Company.1984. 
e-ISSN : 2621-4105

Marsetio, Mengembalikan Kejayaan Maritim, Jurnal Universitas Pertahanan, Jakarta 2018.

R Cribb, Indonesia as an Archipelago : Managing Islands, Managing the Seas. Institute of Southeast Asian Studioes, Singapore, 2009.

SK.Wahyono, Indonesia Negara Maritim, Penerbit Teraju, 2009

Harjo Susmoro, The Spearhead of Sea Power, Pandiva Buku, Yogyakarta 2019.

\section{Jurnal}

A Octavian, Sosiologi Maritim : Rezim Pengelolaan Maritim Indonesia, Jurnal Kajian Lemhanas RI Ed. 14, 2012.

Cristian Bueger, "What is Maritime Security?", Marine Policy Vol. 532015.

Dhiana Puspitawati dan Kristiyanto, Urgensi Pengaturan Keamanan Maritim Nasional di Indonesia”, Jurnal Media Hukum 24 (1), 2017.

http://dx.doi.org/10.18196/jmh.2017.0085.14-23

Muhar Junef., Implementasi Poros Maritim Dalam Perspektif Kebijakan, Jurnal Penelitian Hukum DE JURE 19 (3), 2019. https://doi.org/10.30641/dejure.2019.V19.303-322

Kandar, Memanfaatkan Konflik di Laut Tiongkok Selatan guna Meningkatkan Stabilitas Keamanan Nasional, Jurnal Kajian Lemhannas RI, Edisi 36. Desember 2018

Philipus Hadjon, Tentang Wewenang, Yuridika 5\&6 (XII), 1999.

Victor Muhamad Simela, Indonesia Menuju Poros Maritim Dunia, Jurnal Hubungan Internasional 6(21), 2014.

Rujito Dibyo Asmoro, Peran Indonesia dalam Menjaga Stabilitas guna Mewujudkan Indonesia sebagai Negara Poros Maritim Dunia, Jurnal Kajian Lemhannas RI, Edisi 36, 2018.

Shanti Dwi Kartika, “Keamanan Maritim Dari Aspek Regulasi Dan Penegakan Hukum”, Jurnal Negara Hukum 5(2), 2014. http://dx.doi.org/10.22212/jnh.v5i2.238

Bernard Kent Sondakh Pengamanan Wilayah Laut Indonesia,Jurnal Hukum Internasional, Fakultas Hukum Universitas Indonesia, Jakarta, 2004.

Syaiful Anwar, Keamanan Maritim Indonesia Dalam Analisa Kepentingan, Ancaman Dan Kekuatan Laut, Jurnal Pertahanan 6 (3), 2016.

Yusuf, Efendi, Wawasan Maritim Mengapa Belum Bergema?, Jurnal Jalasena 3, 2013.

\section{Undang-Undang}

UUD NRI 1945

UU No 32 Tahun 2014 tentang Kelautan

UU No. 17 Tahun 2008 tentang Pelayaran

UU No 34 Tahun 2004 tentang Tentara Nasional Indonesia

UU No. 2 Tahun 2002 tentang Kepolisian

UU No. 3 Tahun 2002 tentang Pertahanan Negara

UU No 6 Tahun 1996 tentang Perairan Indonesia

Peraturan Presiden Nomor 178 Tahun 2014 Tentang Badan Keamanan Laut

Peraturan Presiden Nomor 16 Tahun 2017 Tentang Kebijakan Kelautan Indonesia

Peraturan Presiden Nomor 97 Tahun 2015 Tentang Kebijakan Umum Pertahanan Negara Tahun 2015-2019 